\title{
Publisher Correction to: Uptake of $A \beta$ by OATPs might be a new pathophysiological mechanism of Alzheimer disease
}

\author{
Jinhua Wen ${ }^{1 *}{ }^{*}$, Menghua Zhao ${ }^{2 \dagger}$, Wenxiong Sun ${ }^{1}$, Xiaohua Cheng ${ }^{1}$, Luyi Yu ${ }^{1}$, Duanwen Cao ${ }^{1}$ and Pu Li ${ }^{1}$
}

\section{Publisher Correction to: BMC Neurosci 22:53 (2021) https://doi.org/10.1186/s12868-021-00658-9}

Following publication of the original article [1], it was reported that a co-first authorship designation was missing for Jinhua Wen and Menghua Zhao. The corrected authorship list is available in this Correction article and the original article has been corrected. The publishers apologize for the error.

\section{Reference}

1. Wen J, Zhao M, Sun W, Cheng X, Yu L, Cao D, Li P. Uptake of A 3 by OATPs might be a new pathophysiological mechanism of Alzheimer disease. BMC Neurosci. 2021;22:53. https://doi.org/10.1186/s12868-021-00658-9.

\section{Publisher's Note}

Springer Nature remains neutral with regard to jurisdictional claims in published maps and institutional affiliations.

\section{Author details}

${ }^{1}$ Departmentof GCP/Psychosomatic Medicine, The First Affiliated Hospital

of Nanchang University, Nanchang, China. ${ }^{2}$ School of Pharmacy, Nanchang

University, Nanchang, China.

Published online: 29 September 2021

The original article can be found online at https://doi.org/10.1186/s12868021-00658-9.

\footnotetext{
*Correspondence: wenjh8606@163.com

†'Jinhua Wen and Menghua Zhao are co-first authors

1 Departmentof GCP/Psychosomatic Medicine, The First Affiliated Hospital

of Nanchang University, Nanchang, China

Full list of author information is available at the end of the article
}

(c) The Author(s) 2021. Open Access This article is licensed under a Creative Commons Attribution 4.0 International License, which permits use, sharing, adaptation, distribution and reproduction in any medium or format, as long as you give appropriate credit to the original author(s) and the source, provide a link to the Creative Commons licence, and indicate if changes were made. The images or other third party material in this article are included in the article's Creative Commons licence, unless indicated otherwise in a credit line to the material. If material is not included in the article's Creative Commons licence and your intended use is not permitted by statutory regulation or exceeds the permitted use, you will need to obtain permission directly from the copyright holder. To view a copy of this licence, visit http://creativecommons.org/licenses/by/4.0/The Creative Commons Public Domain Dedication waiver (http//creativeco mmons.org/publicdomain/zero/1.0/) applies to the data made available in this article, unless otherwise stated in a credit line to the data. 